\title{
Faktor Prediktor Kematian Anak dengan Infeksi HIV yang Mendapat Terapi Antiretrovirus di RSUP Dr. Sardjito Yogyakarta dan RSUP Dr. Kariadi Semarang
}

Dyah Perwitasari, ${ }^{*}$ Eggi Arguni, ${ }^{*}$ Cahya Dewi Satria, ${ }^{*}$ MMDEAH Hapsari**

*Bagian Ilmu Kesehatan Anak, Fakultas Kedokteran Universitas Gadjah Mada, RSUP Dr. Sardjito, Yogyakarta

**Bagian Ilmu Kesehatan Anak, Fakultas Kedokteran Universitas Diponegoro, RSUP Dr. Kariadi, Semarang

Latar belakang. Kasus infeksi HIV pada anak di Indonesia semakin meningkat dengan angka kematian yang cukup tinggi. Angka kematian anak HIV yang menjalani terapi antiretrovirus disebabkan oleh berbagai faktor.

Tujuan. Mengetahui faktor prediktor yang memengaruhi kematian anak dengan infeksi HIV yang telah mendapat terapi antiretrovirus. Metode. Penelitian studi kasus-kontrol dengan matching usia pada anak dengan infeksi HIV yang mendapat terapi ARV di RSUP Dr. Sardjito dan RSUP Dr. Kariadi dari Januari 2007 sampai dengan Desember 2013. Kelompok kasus adalah pasien meninggal dan kelompok kontrol adalah pasien yang hidup setelah mendapat terapi ARV. Data diambil dari catatan medis dengan kuesioner terstruktur. Data dianalisis dengan SPSS 17.0.

Hasil. Didapatkan 96 anak dirawat dengan infeksi HIV dan menggunakan terapi ARV selama periode penelitian. Dua puluh pasien meninggal setelah menerima ARV sebagai kasus dan 20 pasien hidup sebagai kelompok kontrol. Pada analisis bivariat terdapat hubungan yang bermakna antara status gizi, stadium klinis WHO, ketaatan kunjungan, lama terapi ARV terhadap kematian. Pada analisis multivariat, ketidaktaatan kunjungan memiliki OR 13,8 (IK95\%: 1,04-184,02) dengan nilai p<0,05 dan lama terapi ARV $\leq 6$ bulan memiliki OR 22,133 (IK95\%: 1,202-407,60).

Kesimpulan. Ketidaktaatan kunjungan ke Poliklinik dan lama terapi ARV $\leq 6$ bulan merupakan faktor prediktor yang berpengaruh terhadap kematian pada anak dengan infeksi HIV yang mendapat terapi ARV. Namun, lama terapi ARV $\leq 6$ bulan merupakan faktor yang paling berpengaruh terhadap kematian. Sari Pediatri 2016;18(3):204-8

Kata kunci: prediktor, kematian, HIV, anak

\section{Predicting Factors for Mortality among HIV Infection Children Receiving Antiretroviral Therapy in Dr. Sardjito Hospital Yogyakarta and Dr. Kariadi Hospital Semarang}

Dyah Perwitasari, ${ }^{*}$ Eggi Arguni, ${ }^{*}$ Cahya Dewi Satria, ${ }^{*}$ MMDEAH Hapsari**

Background. HIV infected children in Indonesia has increased with a high mortality rate. The high mortality rate of HIV infected children undergoing antiretroviral therapy is caused by various factors.

Objective. To determine the factor predictors that affect the mortality of children with HIV infection who receive antiretroviral therapy (ARV).

Methods. We conducted a case-control study with maching on age in HIV infected children who receive ARV therapy in Dr. Sardjito Hospital and Dr. Kariadi Hospital began January 2007 until December 2013. As the cases were children who died after receiving ARV therapy, while the control was surviving children at the time of study. Data retrieved from medical records using a structured quetionnaire. Data were analyzed with SPSS 17.0.

Results. A total of 96 children were treated with HIV infection and use ARV therapy during the study period. Twenty children died after receiving ARV as case and 20 children survived as control. On bivariate analysis there is a significant relationship between nutritional status, WHO clinical stage, follow up compliance, and duration of ARV therapy with mortality. On multivariate analysis, disobedience of visit OR 13,8 (95\% CI 1,04-184,02; p <0,05) and duration of ARV therapy $\leq 6$ months OR 22,133 (95\% CI 1,202407,60; $\mathrm{p}<0,05)$.

Conclusion. No routine visite to the clinic and $\leq 6$ months duration of ARV therapy as factors predictor mortality in children with HIV infection that receiving ARV therapy. However $\leq 6$ months duration of ARV therapy is the most factor predictor mortality. Sari Pediatri 2016;18(3):204-8

Keywords: predictor, mortality, HIV, children

Alamat korespondensi: Dr. Dyah Perwitasari, Dr. Eggi Arguni, SpA. Bagian Ilmu Kesehatan Anak, Fakultas Kedokteran Universitas Gadjah Mada, RSUP Dr. Sardjito, Yogyakarta. Email: dyahperwitasari9310@gmail.com 
Dyah Perwitasari dkk: Faktor prediktor kematian anak dengan infeksi HIV yang mendapat terapi ARV

$\mathrm{H}$

uman imunodeficiency virus (HIV) merupakan penyakit yang mematikan. Kumpulan gejala akibat penurunan imun tubuh yang disebabkan oleh virus tersebut dikenal dengan acquired immuno deficiency syndrome (AIDS) dan merupakan penyakit infeksi yang menjadi masalah kesehatan global dan tersebar hampir di seluruh negara di dunia, termasuk Indonesia. ${ }^{1-4}$ Berikut ini adalah jumlah kumulatif kasus AIDS di Indonesia menurut golongan umur <1, 1-4, 5-14, dan 15-19 tahun berturut-turut 267, 395, 198, dan 1069 kasus. Data hingga Desember 2013 tercatat 117 kasus anak dengan infeksi HIV yang pernah dirawat di RSUP Dr. Sardjito Yogyakarta dan 82 kasus di RSUP Dr. Kariadi Semarang. Penelitian tentang faktor risiko kematian anak dengan infeksi HIV yang menjalani terapi antiretrovirus belum pernah dilakukan di RSUP Dr. Sardjito Yogyakarta dan RSUP Dr. Kariadi Semarang. Faktor risiko ini penting diketahui untuk meningkatkan kualitas hidup anak dan memperpanjang usia.

\section{Metode}

Penelitian metode kasus kontrol dengan dilakukan matching terhadap usia. Subjek penelitian diambil dari data rekam medis semua pasien anak dengan infeksi HIV yang mendapat terapi ARV dan memenuhi kriteria pemilihan mulai 1 Januari 2007 hingga 31 Desember 2013 dirawat di RSUP Dr. Sardjito dan RSUP Dr. Kariadi.

Kriteria inklusi adalah semua pasien anak usia 0-18 tahun yang telah terdiagnosis HIV dan mendapat terapi ARV yang dirawat di RSUP Dr. Sardjito dan RSUP Dr. Kariadi. Kriteria ekslusi adalah pasien anak yang terinfeksi HIV dengan catatan medis yang tidak lengkap, pasien yang meninggal karena sebab lain seperti kecelakaan. Subyek penelitian dibagi menjadi dua kelompok, anak dengan infeksi HIV yang meninggal setelah mendapat terapi ARV (kasus) dan anak dengan infeksi HIV yang survive setelah mendapat terapi ARV (kontrol). Data diolah menggunakan program SPSS 17.0 (SPSS Inc. Chicago). Penelitian ini sudah memperoleh kelaikan etik dari Komite Etik Penelitian Kedokteran Kesehatan, Fakultas Kedokteran Universitas Gajah Mada.

\section{Hasil}

Didapatkan 199 anak dengan infeksi HIV yang berobat ke RSUP Dr. Sardjito Yogyakarta dan RSUP Dr. Kariadi Semarang, 13 anak meninggal sebelum mendapat terapi ARV, 20 meninggal setelah mendapatkan terapi ARV sebagai kasus.

Pada Tabel 1 tertera karakteristik dasar subyek penelitian, didapatkan laki-laki 23 anak dari total 40 subyek penelitian. Sepuluh $(43,48 \%)$ anak meninggal dan $13(56,52 \%)$ hidup setelah mendapat terapi ARV. Subyek perempuan 17 anak dari total 40 subyek penelitian, $10(58,82 \%)$ meninggal dan 7 (41,18\%) hidup setelah mendapat terapi ARV. Rerata usia adalah $5,30 \pm 3,13$ tahun. Umur 1-5 tahun saat terdiagnosis 24 dari 40 subyek penelitian, 12 (50\%) meninggal dan 12 (50\%) anak hidup. Umur 6-18 tahun saat terdiagnosis 16 anak dari 40 subyek penelitian, $8(50 \%)$ meninggal dan 8 (50\%) anak hidup. Tingkat pendidikan orang tua dikelompokkan menjadi tidak sekolah 1 orang, SD 1, SMP 7, SMU 27, perguruan tinggi 4 orang, terbanyak adalah SMU 14 (51,85\%) pada kelompok kasus dan $13(48,15 \%)$ pada kelompok kontrol. Lama mendapat terapi ARV $\leq 6$ bulan 11 anak, 10 (90,9\%) meninggal dan $1(9,1 \%)$ hidup.

Pada Tabel 2 tertera status gizi, stadium klinis WHO, ketaatan kunjungan, lama terapi ARV pada kelompok kasus dan kelompok kontrol berbeda bermakna $(\mathrm{p}<0,05)$. Di antara semua pasien yang meninggal, $20(57,1 \%)$ anak mempuyai status gizi kurang/buruk, sedangkan dari semua pasien yang hidup hanya 15 (42,8\%) anak yang mempunyai status gizi kurang/buruk (OR 0,43; p=0,047; IK95\%: 0,29$0,62)$. Stadium klinis 3-4 WHO pada kelompok pasien yang meninggal terdapat $17(65,4 \%)$ anak, sedangkan dari semua pasien yang hidup terdapat $9(34,6 \%)$ anak mempunyai stadium klinis 3-4 (OR 0,93; $\mathrm{p}=0,02$; IK95\%: 1,53-31,38). Terdapat $10(62,5 \%)$ yang meninggal mempunyai kadar CD $4<10 \%$, terdapat 6 $(37,5 \%)$ anak yang hidup mempunyai kadar CD $4<10$ (OR 2,33, p=0,2; IK95\%: 0,64-8,54). Pada kelompok pasien yang meninggal $7(58,3 \%)$ anak mempunyai kadar $\mathrm{Hb}<8 \mathrm{~g} / \mathrm{dL}$, sedangkan pada kelompok pasien yang hidup terdapat $5(41,7 \%)$ mempunyai kadar $\mathrm{Hb}<8$ g/dL (OR 1,62; p=0,49; IK95\%: 0,42-6,34). Pada kelompok pasien yang meninggal terdapat kejadian infeksi oportunistik berupa diare $17(58,6 \%)$, pneumonia $10(71,4 \%)$, tuberkulosis $13(52,0 \%)$ anak. Sementara pada kelompok yang hidup kejadian infeksi 
Dyah Perwitasari dkk: Faktor prediktor kematian anak dengan infeksi HIV yang mendapat terapi ARV

Tabel 1. Karakteristik dasar pasien HIV anak yang mendapat terapi ARV

\begin{tabular}{llll}
\hline Karakteristik & Kasus (\%) & Kontrol (\%) & Nilai p \\
\hline $\begin{array}{l}\text { Jenis kelamin } \\
\text { Laki-laki }\end{array}$ & $10(43,5)$ & $13(56,5)$ & 0,549 \\
$\quad$ Perempuan & $10(58,8)$ & $7(41,2)$ & \\
Umur saat terdiagnosis (tahun) & & & \\
$\quad 1-5$ & $12(50,0)$ & $12(50,0)$ & 1,00 \\
$\quad 6-8$ & $8(50,0)$ & $8(50,0)$ & \\
Pendidikan orang tua & & & \\
$\quad$ Tidak sekolah & $1(100,0)$ & $0(0,0)$ & \\
SD & $1(100,0)$ & $0(0,0)$ & \\
SMP & $2(28,6)$ & $5(71,4)$ & \\
SMU & $14(51,8)$ & $13(48,2)$ & \\
$\quad$ Perguruan tinggi & $2(50,0)$ & $2(50,0)$ & \\
Lama terapi ARV (bulan) & & & \\
$\quad \leq 6$ & $10(90,9)$ & $1(9,1)$ & \\
$>6$ & $10(34,5)$ & $19(65,5)$ & \\
\hline
\end{tabular}

Tabel 2. Analisis bivariat faktor risiko kematian pada anak HIV yang mendapat terapi ARV

\begin{tabular}{|c|c|c|c|}
\hline Variabel & Kasus (\%) & Kontrol (\%) & Nilai p \\
\hline \multicolumn{4}{|l|}{ Status gizi } \\
\hline Kurang/buruk & $20(57,1)$ & $15(42,8)$ & \multirow[t]{2}{*}{$\left.0,047^{*}\right)$} \\
\hline Baik & $0(0,0)$ & $5(100,0)$ & \\
\hline \multicolumn{4}{|l|}{ Stadium klinis } \\
\hline Stadium 3-4 & $17(65,4)$ & $9(34,6)$ & \multirow[t]{2}{*}{$\left.0,019^{*}\right)$} \\
\hline Stadium 1-2 & $3(21,4)$ & $11(78,6)$ & \\
\hline \multicolumn{4}{|l|}{ Kadar CD4 } \\
\hline$<10 \%$ & $10(62,5)$ & $6(37,5)$ & \multirow[t]{2}{*}{$0,197^{* *}$} \\
\hline$\geq 10 \%$ & $10(41,7)$ & $14(58,3)$ & \\
\hline \multicolumn{4}{|c|}{ Kadar hemoglobin (mg/dL) } \\
\hline$<8$ & $7(58,3)$ & $5(41,7)$ & \multirow[t]{2}{*}{$0,49^{* *}$} \\
\hline$\geq 8$ & $13(46,4)$ & $15(53,6)$ & \\
\hline \multicolumn{4}{|l|}{ Kejadian diare } \\
\hline $\mathrm{Ya}$ & $17(58,6)$ & $12(41,4)$ & \multirow[t]{2}{*}{$0,155^{*}$} \\
\hline Tidak & $3(27,3)$ & $8(72,7)$ & \\
\hline \multicolumn{4}{|c|}{ Kejadian tuberkulosis } \\
\hline Ya & $13(52,0)$ & $12(48,0)$ & \multirow[t]{2}{*}{$0,744^{* *}$} \\
\hline Tidak & $7(46,7)$ & $8(53,3)$ & \\
\hline \multicolumn{4}{|c|}{ Kejadian pneumonia } \\
\hline $\mathrm{Ya}$ & & & \\
\hline \multirow[t]{2}{*}{ Tidak } & $10(71,4)$ & $4(28,6)$ & \multirow[t]{2}{*}{$0,096^{* *}$} \\
\hline & $10(38,5)$ & $16(61,5)$ & \\
\hline \multicolumn{4}{|c|}{ Ketaatan kunjungan } \\
\hline $\mathrm{Ya}$ & $7(87,5)$ & $1(12,5)$ & \multirow[t]{2}{*}{0,044} \\
\hline Taat & $13(40,6)$ & $19(59,4)$ & \\
\hline \multicolumn{4}{|c|}{ Lama terapi ARV (bulan) } \\
\hline$\leq 6$ & $10(90,9)$ & $1(9,1)$ & \multirow[t]{2}{*}{0,001} \\
\hline$>6$ & $10(34,5)$ & $19(65,5)$ & \\
\hline
\end{tabular}


Dyah Perwitasari dkk: Faktor prediktor kematian anak dengan infeksi HIV yang mendapat terapi ARV

Tabel 3. Hasil analisis multivariat

\begin{tabular}{lccc}
\hline Variabel & $\mathrm{p}$ & $\mathrm{OR}$ & $\mathrm{IK} 95 \%$ \\
\hline Stadium klinis WHO & 0,104 & 4,781 & $0,725-31,528$ \\
Kadar CD4 & 0,434 & 1,887 & $0,385-9,253$ \\
Diare & 0,447 & 2,154 & $0,298-15,591$ \\
Pneumonia & 0,226 & 2,777 & $0,532-14,502$ \\
Ketaatan kunjungan & 0,047 & 13,813 & $1,037-184,021$ \\
Lama terapi ARV & 0,037 & 22,133 & $1,202-407,640$ \\
\hline
\end{tabular}

oportunistik berupa diare $12(41,4 \%)$, pneumonia $4(28,6 \%)$, tuberkulosis $12(48,0 \%)$ anak dengan masing-masing nilai $\mathrm{p}>0,05$.

Dari semua pasien yang meninggal terdapat 7 (87,5\%) anak yang tidak taat berkunjung ke poli untuk mendapatkan ARV, sedangkan pada kelompok yang hidup hanya terdapat 1 anak (12,5\%) anak yang tidak taat berkunjung (OR 10,23; $\mathrm{p}=0,04$; IK 95\%: 1,12$93,34)$. Sebanyak 10 anak $(90,9 \%)$ yang meninggal mendapat terapi ARV selama $\leq 6$ bulan, sedangkan pada kelompok anak yang hidup hanya 1 anak $(9,1 \%)$ yang mendapat terapi ARV $\leq 6$ bulan (OR 19,0; $\mathrm{p}=0,001$; IK95\%: 2,11-170,38).

Pada analisis multivariat ketaatan kunjungan (OR 13,8; $\mathrm{p}=0,047$; IK95\%: 1,04-184,02) dan lama terapi ARV (OR 22,133; $p=0,037$; IK95\%: 1,202-407,640) terdapat hubungan yang bermakna dengan kematian.

\section{Pembahasan}

Pada analisis bivariat didapatkan status gizi, stadium klinis WHO, ketaatan kunjungan, dan lama terapi ARV. Pada analisis multivariat didapatkan ketidaktaatan kunjungan dan lama terapi $A R V \leq 6$ bulan merupakan faktor prediktor kematian. Namun, lama terapi ARV $\leq 6$ bulan merupakan faktor prediktor kematian yang paling berpengaruh.

Zanoni $\mathrm{dkk}^{9}$ melakukan penelitian terhadap 47 anak dengan infeksi HIV yang mendapat terapi ARV melaporkan bahwa status gizi WHZ $<-2$ memiliki HR 0,53 untuk terjadinya kematian (IK 95\%: 0,43-0,64) dan Wamalwa $\mathrm{dkk}^{7}$ melaporkan status gizi $\mathrm{WHZ}<-2$ dengan HR 3,41 (IK 95\%: 1,28-9,08). ${ }^{6}$, Pada analisis bivariat status gizi kurang/buruk memiliki OR 0,43 (IK 95\%: 0,29-0,62). Hal tersebut menunjukkan terdapat hubungan antara status gizi dengan kematian sehingga penilaian dan dukungan gizi menjadi bagian penting dalam perawatan anak dengan infeksi HIV.
Hasil penelitian yang dilakukan oleh Wamalwa $\mathrm{dkk}^{7}$ melaporkan stadium klinis 4 WHO memiliki HR 3,08 (IK95\%: 1,17-8,13) berhubungan dengan kematian. Dalam penelitian kami, stadium klinis 3-4 WHO memiliki OR 4,78 (IK95\%: 0,73-31,53). Infeksi penyerta dan kondisi klinis yang terjadi pada stadium 3- 4 berpengaruh terhadap kematian.

Dalam penelitian kami, kadar CD $4<10 \%$ mempunyai OR 1,89 (IK 95\%: 0,36-9,25). Penelitian lain oleh Gebremedhin ${ }^{8}$ tahun 2013 didapatkan kadar CD4 <10\% memiliki HR 2,98 (IK95\%: 1,12-7,94), penelitian oleh Zanoni $\mathrm{dkk}^{9}$ tahun 2011 kadar CD4 < 10\% memiliki HR 2,49 (IK95\%: 1,33-4,66). CD4 adalah parameter terbaik untuk mengukur imunodefisiensi. Semakin rendah kadar CD4 menunjukkan semakin berat defisiensi imun yang terjadi.

Pada penelitian kami, kejadian diare memiliki OR 2,15 (IK95\%: 0,29-15,59). Zanoni $\mathrm{dkk}^{9}$ melaporkan diare kronis memiliki HR 3,02 (IK95: 1,69-5,39) dan Gebremedhin ${ }^{8}$ melaporkan diare kronis memiliki HR 4,63 (IK95\% 1,50-14,31). Hal tersebut menunjukkan bahwa diare kronis berpengaruh terhadap kematian anak dengan infeksi HIV yang mendapat terapi ARV. Dengan demikian, usaha preventif dan edukasi untuk menjaga kebersihan harus diberikan agar kejadian diare pada anak dengan infeksi HIV dapat dicegah. Pneumonia memiliki OR 2,78 (IK95\% 0,53-14,50), secara statistik tidak bermakna, tetapi secara klinis pneumonia menjadi salah satu penyebab kematian anak dengan infeksi HIV sehingga pemberian profilaksis kotrimoksasol diberikan pada anak dengan kadar CD4 yang rendah.

Ketaatan kunjungan merupakan salah satu faktor prediktor terhadap kematian. Penelitian kami menunjukkan bahwa bila anak tidak taat minum obat ARV, yang dapat dilihat dari ketaatan berkunjung ke Poliklinik untuk mendapatkan obat ARV, akan mempunyai risiko kematian 13 kali dibanding anak 
Dyah Perwitasari dkk: Faktor prediktor kematian anak dengan infeksi HIV yang mendapat terapi ARV

dengan infeksi HIV yang taat minum obat ARV. Ketaatan minum obat juga diteliti oleh Kabue $\mathrm{dkk}^{10}$ terhadap 1687 pasien di Malawi, Lesotho, dan Swaziland. Dalam penelitian ini, 90,5\% anak dengan infeksi HIV yang menjadi subyek penelitian mengalami peningkatan status imun setelah pemberian ARV. Perlu dipahami bahwa obat ARV tidak untuk menyembuhkan HIV, tetapi dapat menurunkan angka kesakitan dan kematian serta memperbaiki kualitas hidup pada orang dewasa maupun anak karena pengaruhnya terhadap peningkatan sistem imun. ${ }^{11}$

Lama terapi ARV $\leq 6$ bulan memiliki OR 22,13 (IK 95\%: 1,202-407,640). Sutcliffe $\mathrm{dkk}^{6}$ melakukan penelitian terhadap anak dengan infeksi HIV di Zambia melaporkan bahwa kematian tertinggi terjadi pada 3 bulan pertama setelah mendapat terapi ARV dihubungkan dengan usia, anemia dan status gizi. Penelitian lain di Amerika, Eropa, dan Afrika Selatan melaporkan bahwa kematian terbanyak terjadi pada 6 bulan pertama setelah mendapatkan terapi ARV. Pengamatan 6 bulan pertama pada kasus dalam terapi ARV merupakan masa penting. Diharapkan terjadi perbaikan klinis dan imunologis, tetapi juga harus diwaspadai kemungkinan toksisitas obat dan/atau kejadian IRIS. Komplikasi dapat terjadi pada minggu pertama umumnya lebih banyak ditemukan pada anak defisiensi imun berat.

Salah satu kelemahan dari penelitian kami adalah sampel yang terkumpul tidak memenuhi jumlah sampel minimal yang diperhitungkan. Jumlah sampel yang sedikit akan dapat memengaruhi hasil penelitian. Penggunaan metode retrospektif untuk mencari faktor prediktor yang berpengaruh menyebabkan kemungkinan terdapat bias akibat data rekam medis yang kurang lengkap.

\section{Kesimpulan}

Ketidaktaatan kunjungan ke Poliklinik dan lama terapi ARV $\leq 6$ bulan merupakan faktor prediktor yang berpengaruh terhadap kematian pada anak dengan infeksi HIV yang mendapat terapi ARV. Namun, lama terapi $A R V \leq 6$ bulan merupakan faktor yang paling berpengaruh terhadap kematian.

\section{Daftar pustaka}

1. Matondang CS, Kurniati N. Infeksi HIV pada Bayi dan anak. Buku Ajar Alergi-Imunologi Anak, Jakarta. Badan penerbit IDAI; 2010.h.378-413.

2. UNAIDS. Report on the Global AIDS Epidemic. 2012. Geneva: UNAIDS;2012.

3. UNAIDS/WHO. AIDS Epidemic update 2009. Geneva: UNAIDS/WHO;2009.

4. Nasronudin, penyunting. HIV dan AIDS Pendekatan biologi molekuler, klinis dan sosial. Surabaya: Airlangga University Press; 2007.

5. Ditjen PP \& PL Kemenkes RI. Statistik kasus HIV/AIDS di Indonesia. Jakarta: Ditjen PP \& PL Kemenkes; RI 2012.

6. Sutcliffe CG, van Dijk JH, Munsanje B. Risk factors for pretreatment mortality among HIV-infected children in rural Zambia: A cohort study. PLos ONE 2011;6:1-9.

7. Wamalwa DC, Obimbo EM, Farquhar C, Richardson BA, Mbori-Ngacha DA. Predictors of mortality in HIV-1 Infected children on antiretroviral therapy in Kenya: a prospective cohort. BMC Pediatrics 2010;10:33-40.

8. Gebremedhin A, Gebremariam S, Haile F, Weldearegawi B, Decotelli. Predictors of mortality among HIV infected children on anti-retroviral therapy in Mekelle Hospital, Northern Ethiopia: a retrospective cohort study. BMC Pub Health 2013;13:1047.

9. Zanoni BC, Phungula T, Zanoni HM. Risk factors associated with increased mortality among HIV infected children initiating antiretroviral therapy (ART) in South Africa: PLos ONE 2011;6:1-6.

10. Kabue MM, Buck WC, Wanless SR, Cox CM, McCollum ED, Caviness AC, dkk. Mortality and clinical outcomes in hiv-infected children on antiretroviral therapy in Malawi, Lesotho, and Swaziland. Pediatr 2012;130:e591-9

11. WHO. Anak dengan HIV/AIDS dalam pedoman pelayanan kesehatan anak di rumah sakit. Jakarta: WHO; 2009.h.223-9. 